\title{
Multi-phase tectonic structures in the collision zone of the Kolyma-Omolon microcontinent and the eastern margin of the North Asian craton, Northeastern Russia
}

\author{
A. V. Prokopiev and V. S. Oxman \\ Diamond and Precious Metal Geology Institute, Siberian Branch, Russian Academy of Sciences, Yakutsk, Russia
}

\begin{abstract}
The sequence of formation of structures is established in the zone of junction of the eastern margin of the North Asian craton and the northeastern flank of the Kolyma-Omolon microcontinent, in the area of bend of the Kolyma structural loop. Detailed structural studies revealed two phases in the formation of Mesozoic structures - an early thrust phase and a late strike-slip phase. Structures formed during each of the phases are described. Thrust structures are represented by the Setakchan nappe on which the minimum amount of horizontal displacement is estimated at $13-15 \mathrm{~km}$. Later superposed left-lateral strike-slip faults have a north strike. Formation of these latter structures occurred during the second phase of collision between the Kolyma-Omolon microcontinent and the eastern margin of the North Asian craton.
\end{abstract}

\section{Introduction}

The study region is located on the northwestern side of the Kolyma-Omolon microcontinent, in the area of the bend of the Kolyma structural loop, where the fold structures change their strike from northwest to northeast (Fig. 1). From west to east, the microcontinent here includes the Polousnyy synclinorium, the Nagondzha turbidite terrane, and the northern Omulevka miogeoclinal terrane composed mainly of Ordovician to Lower Carboniferous carbonate and terrigenouscarbonate rocks (Parfenov and Kuz'min, 2001). The studies were mainly conducted on the northwestern side of the Nagondzha terrane, in the area of its junction with structures in the Polousnyy synclinorium along the Setakchan thrust. In the east, the terrane makes contact with the rocks of the Omulevka terrane along the Nal'chan fault (Fig. 1). The Nagondzha terrane is composed, in the lower

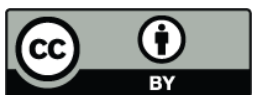

Correspondence to: A. V. Prokopiev (prokopiev@diamond.ysn.ru) part of the section, of Lower Devonian carbonate rocks overlain by Carboniferous-Permian hemipelagic volcanogenicterrigenous-siliceous rocks exposed in a narrow band along the Nal'chan fault. The upper part of the section consists of Triassic and Jurassic sandy-clayey flysch deposits up to $1 \mathrm{~km}$ in total thickness, making up most of the terrane's area. On the south, the terrane is adjoined by the tectonic zone of the Polousnyy synclinorium that is composed of the Lower to Middle Jurassic turbidites with a thickness exceeding $1.5 \mathrm{~km}$ (Parfenov and Kuz'min, 2001). It is generally assumed (Parfenov, 1995; Prokopiev, 2000; Oxman, 2000; Oxman and Prokopiev, 2000; Prokopiev and Kaskevich, 2000; Parfenov and Kuz'min, 2001; Parfenov et al., 2003) that thrust structures in the zone of junction of the Kolyma-Omolon microcontinent and the North Asian craton margin originated during frontal collision between the microcontinent and the craton, subsequent to completion of subuction of the oceanic crust of their separating paleoocean, and that strike-slip motions occurred during the following motion of the microcontinent from southeast to northwest (here and hereafter in present-day coordinates) and the closure of a small gulf of the South Anyui ocean.

This paper is based on the results of structural and geometric analyses by the authors during a large-scale geologic survey on the Selennyakh and Uyandina Rivers (northwest tributaries of the Indigirka River) (Fig. 1). The investigation was aimed at establishing the sequence of formation of structures within the two areas, Khulidzhyun and Setakchan, in an attempt to interpret the Late Mesozoic deformation history of the region.

\section{The Khulidzhyun area}

The area (upper reaches of Khulidzhyun Creek, the northeast tributary of Tirekhtyakh Creek, Selennyakh River basin) occurs within the limits of the Setakchan nappe and is confined to the hanging wall of the regional Setakchan thrust (Fig. 1).

Published by Copernicus Publications on behalf of the European Geosciences Union. 


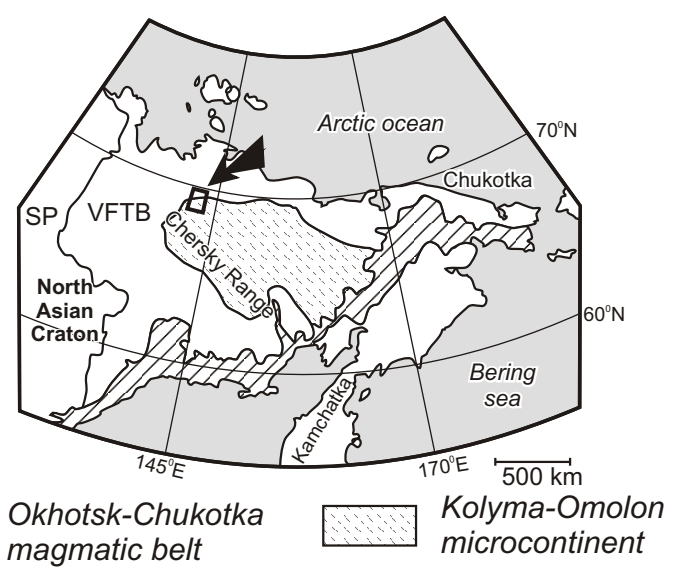

SP - Siberian platform, VFTB - Verkhoyansk fold-and-thrust belt
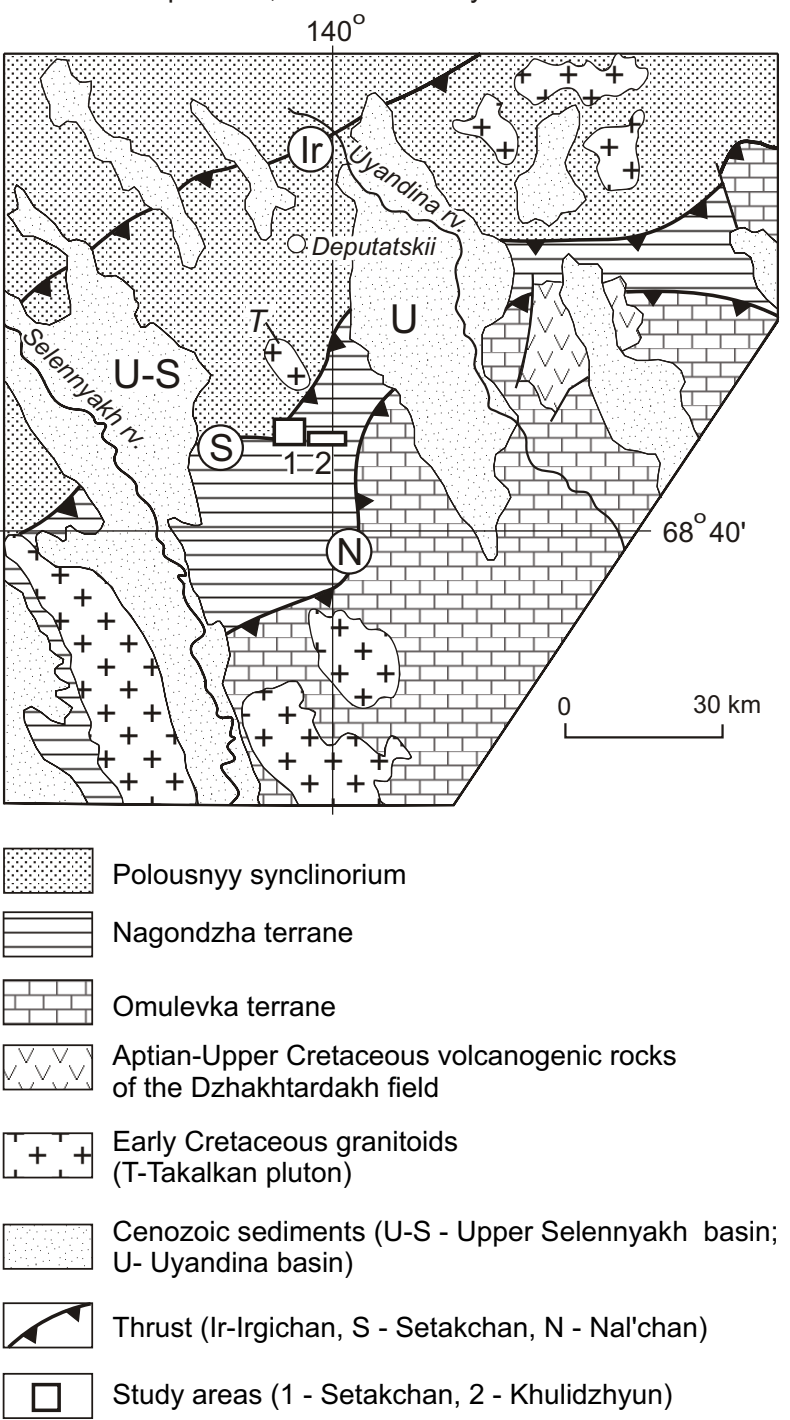

Polousnyy synclinorium

Nagondzha terrane

Omulevka terrane

Aptian-Upper Cretaceous volcanogenic rocks of the Dzhakhtardakh field

Early Cretaceous granitoids (T-Takalkan pluton)

Cenozoic sediments (U-S - Upper Selennyakh basin; U- Uyandina basin)

Thrust (Ir-Irgichan, S - Setakchan, N - Nal'chan)

Study areas (1 - Setakchan, 2 - Khulidzhyun)

Fig. 1. Tectonic map of the southern sector of the Polousnyy synclinorium and the Nagondzha terrane. After Grebennikov et al. (1995) and Parfenov and Kuz'min (2001), modified by the authors. Inset map - location of the study area.
The nappe is formed by allochthonous Upper Triassic (Norian) mainly sandy rocks overlying, along a low-angle thrust, the autochthonous Lower to Middle Jurassic chiefly clayey deposits. The Jurassic rocks in the autochthon display tectonic mélange structures (broken and dismembered formations), which were described in detail in an earlier publication (Oxman and Prokopiev, 2000). This paper presents new data on the structural features of the deformed strata, as well as the geometric characteristics of the nappe. Geologic mapping established that the autochthon of the nappe is exposed in an erosional window, while the allochthon to the northwest is a tectonic klippe composed, like the southeastern side of the area, of Norian sandstone and siltstone (Fig. 2a). The southeastern contact between the klippe and the Lower to Middle Jurassic mélange is exposed in a trench where the Jurassic rocks are found to be in tectonic contact with the Upper Triassic deposits along a plane dipping steeply to the southeast. However, we also established that northwest of the klippe, the Triassic rocks are mainly overturned. From these data, we infer that the fault surface is deformed into a southwest-overturned antiform. The fold is coaxial with numerous small folds in the tectonic mélange zone within the window (Fig. 2a, stereograms 2 and 5). The folds are mainly conical, with a width from a few decimeters to a few tens of meters. The allochthon rocks are deformed into cylindrical folds ranging up to several hundred meters wide. In the tectonic mélange of the autochthon, the cleavage has a predominantly southeast or south dip and is subparallel to the axial planes of tight to isoclinal folds of the first generation $\left(F_{1}\right)$ that are inclined mainly to the northwest. In some areas, the intensity of deformation is high enough for the bedding to become parallel to cleavage $S_{1}$ (Fig. 2a, stereograms 2 , 3 and 5). In this case, the cleavage becomes transpositional (Passchier and Trouw, 1996), and $F_{1}$ folds are rootless, with their limbs isolated from the hinge zone in isoclines whose axial surfaces are parallel to the cleavage. Fold hinge lines $b_{1}$ and lineation of the cleavage and bedding intersection $L_{0 \times 1}$ plunge gently to the southwest and northeast. Within the exposed part of the autochthon, the apparent thickness of the Lower to Middle Jurassic rock units, as measured perpendicular to the cleavage, exceeds $10 \mathrm{~km}$. Since the thickness of deposits of that age does not exceed a few kilometers, even in the central part of the Polousnyy synclinorium, one may assume that the Jurassic sequence in the autochthon is repeated along the thrusts traceable in the mélange zone.

In the allochthon, wide (up to $1 \mathrm{~km}$ ) and linear, commonly overturned, $F_{1}$ folds are associated with low-angle thrusts that form a northwest-verging imbricate fan. These structures, like the tectonic mélange of the autochthon, were formed during the first deformation stage in the region, synchronously with the thrusts. Detachment at the allochthon base is traced along the bottom of the Norian rock sequences, and the minimum horizontal displacement of the allochthon is estimated at $13-15 \mathrm{~km}$ (Fig. 2b). 
The second stage of deformation is related strike-slip motion on northwest-striking faults. The S-shaped (in plan) small $F_{2}$ folds and numerous slickensides indicate that the strike-slip is left-lateral. As a result of strike-slip motions, the early thrusts, linear folds of the allochthon and cleavage of the tectonic mélange of the autochthon were deformed into a large $\mathrm{S}$-shaped (in plan) $F_{2}$ fold up to $6 \mathrm{~km}$ wide (Fig. 2a). This deformation of the early structures is established from the distribution of the poles of the $S_{1}$ cleavage planes of the tectonic mélange in the arc of a small circle, indicating a conical geometry of $F_{2}$ folds, as well as from changing orientation of hinge lines $\left(b_{1}\right)$ of the early $F_{1}$ folds (Fig. 2a, stereogram 2). Hinge lines $\left(b_{2}\right)$ of $F_{2}$ folds plunge steeply to the east-southeast (Fig. 2a, stereogram 5).

\section{The Setakchan area}

The area is located east of the Khulidzhyun area, within the Nagondzha terrane, in the middle reaches of Setakchan Creek the northeast tributary of Tirekhtyakh Creek, Uyandina River basin) (Fig. 3). Here in the canyon, there are perfect exposures of multiply deformed flysch deposits of the Norian age. The structures described here are characteristic of the central zone of the Nagondzha terrane, located between the Nal'chan and Setakchan thrusts (see Fig. 1). The eastern part of the area consists mainly of sandstone of the local zone Otapiria ussuriensis from the middle part of the Norian, while in the west there are exposures of mainly argillaceous rocks of the local zone Monotis ochotica from the lowermost Upper Norian. This indicates the rocks generally dip to the east. The intermediate local zone Monotis scutiformis is either absent from the sequence or faunal remains of this age have not yet been found. Eastward, beyond the borders of the area, poorly fossiliferous Lower to Middle Jurassic rocks make their appearance. Two stages of deformation are recognized here. Structures of the first stage include low-angle thrusts with fault surfaces that dip gently to the east and northeast. In fact, the rock mass represents a set of packages of thrust sheets, each up to a few hundred meters thick, that are separated by thrust surfaces. The thickness of the mylonitized rocks in the fault zones attains a few decimeters. Cleavage is either present in narrow discrete zones or absent altogether. This fact and the lack of metamorphic alteration imply the formation of structures at relatively shallow depths. The thrust structures are mainly typical ramps that form imbricate fan-like systems (Fig. $4 \mathrm{a}$ and b). $F_{1}$ folds are concentric, including both upright to slightly inclined folds and recumbent isoclines (Fig. 4c). The trend of gentle hinge lines $b_{1}$, and the strike of axial surfaces of $F_{1}$ folds and thrust surfaces changes from west to north (Fig. 3). Common fold thrusts are characterized by low-angle thrusts that die out updip in the cores of folds (Fig. 4a). The amount of horizontal displacement on some of the thrusts is a few meters, rarely up to $10-15 \mathrm{~m}$. However, the absence of marker horizons in

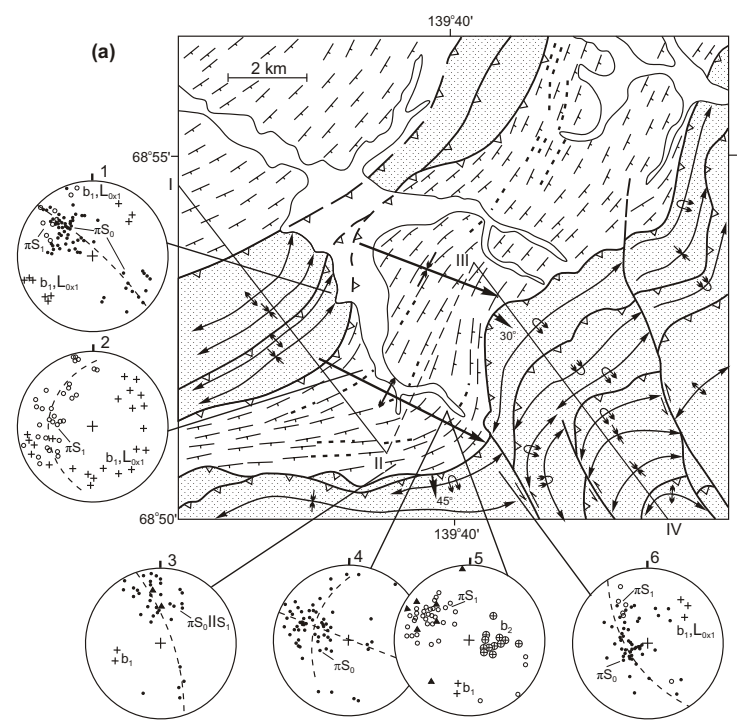

(b)

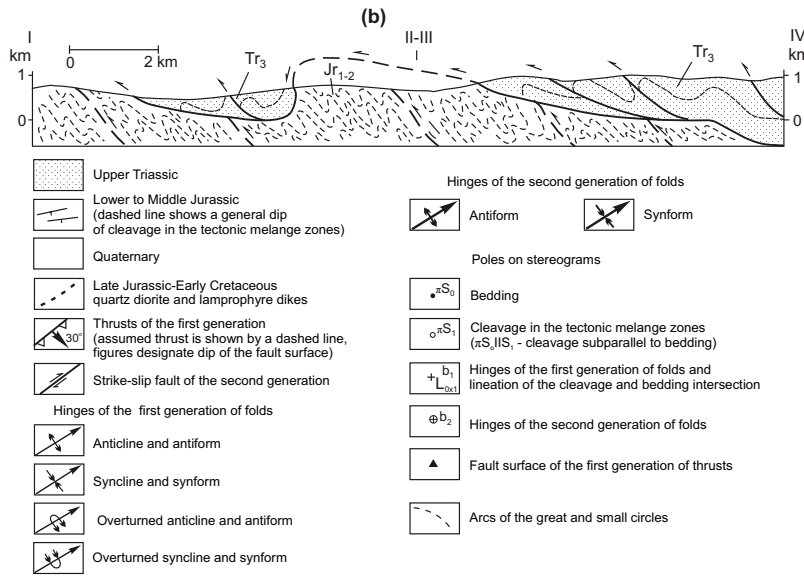

Fig. 2. Tectonic map of the Khulidzhyun area with stereographic projections of structures (a) and geologic section along the I-II-IIIIV line (b). For location see Fig. 1.

the Upper Triassic strata prevents estimating the total amount of motion on the thrusts. The estimated shortening is high, ranging up to $40-50 \%$ on some thrusts. Therefore, the total displacement on the thrusts may have been several tens of kilometers.

In thin (about $1.5 \mathrm{~km}$ ) zones of the syn-thrust tectonic mélange, restricted to the thrust planes (Fig. 4d), there are disrupted sandstone beds in the form of lenses embedded in a schistose matrix of argillaceous rocks, representing a typical "broken formation" (Raymond, 1984). The long axes of the lenses are subperpendicular to the thrust planes, parallel to the westward movement of the rock masses. A characteristic feature of the interstratal detachment zones are numerous small-scale and low-amplitude thrust duplexes (Fig. 4e, f, and g). Kinematics of the thrusts depend on the competence of the host rocks: in largely argillaceous rocks interstratal 


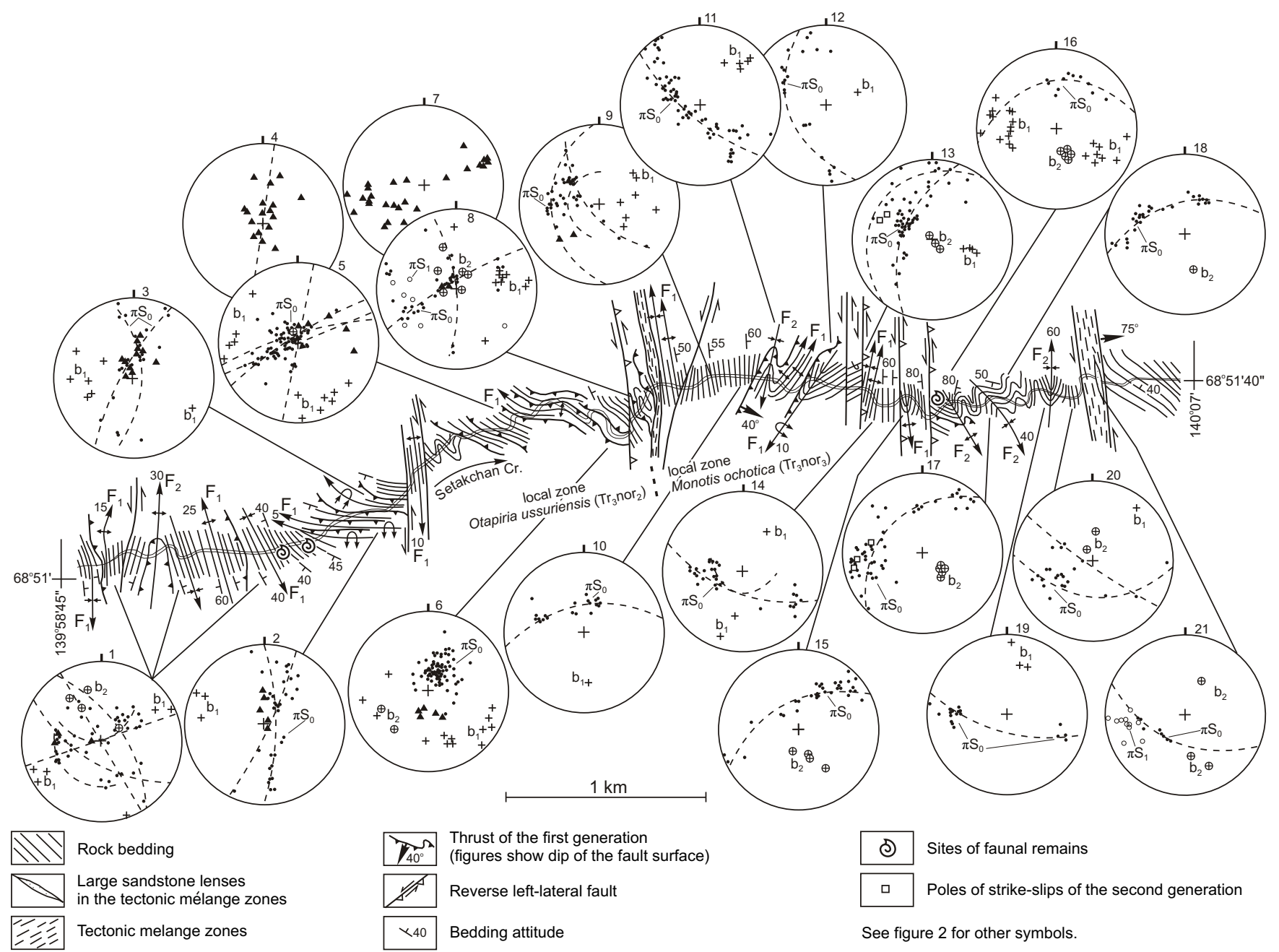

Fig. 3. Tectonic map and stereographic projections of structures along Setakchan Creek. For location see Fig. 1.

detachment thrusts and micro-duplexes are developed, while the rocks with a high percentage of sandstone are deformed into imbricate fans and ramps. As in the Khulidzhyun area, coaxial structures are found here, which are associated with the final stage of thrusting in the same tectonic stress field.

The second-stage structures include faults of dip-slip and strike-slip kinematics and tectonic mélange zones of north strike and east dip. The strike-slip faults have associated folds of the second generation $\left(F_{2}\right)$ superposed on the earlier structures (Fig. 4h). Numerous slickensides and S-shaped $F_{2}$ folds indicate reverse left-lateral strike-slip kinematics. The amplitude of $F_{2}$ folds varies from a few decimeters to $2-3 \mathrm{~km}$. Since this folding involves the previously intensely deformed rock units, $b_{2}$ hinge lines of small $F_{2}$ folds plunge, as a rule, in different directions and their plunges depend on the dip of the earlier deformed bedding or fault surfaces of the thrusts - the steeper dip, the greater the plunge of the hinge lines of the superposed $F_{2}$ folds. Deformation of the earlier inclined planar structures results in conical geometry of almost all $F_{2}$ folds and distribution of the poles in the arcs of small circles on the stereograms (Fig. 3). The axial planes of $F_{2}$ folds dip steeply and are oriented at an angle to the strike of the reverse left-lateral faults. Like the earlier $F_{1}$ folds, $F_{2}$ folds are of concentric type.

Large $F_{2}$ folds have been mapped from changes in the strike of the bedding, the fault surfaces of the early thrusts, and $F_{1}$ fold hinge lines. This is most easily observed on the western side of the area. Comparison of the orientation data for the planar and linear structures presented in stereograms 1-8 (Fig. 3) shows the early structures have been deformed into a large $F_{2}$ fold with an amplitude of several kilometers. The calculated hinge line of the fold plunges to the northeast at an angle of $50-70^{\circ}$.

Zones of the second generation of reverse left-lateral faults range from a few decimeters to $150 \mathrm{~m}$ in width. They include the tectonic mélange observed at the center and in the eastern 
part of the area (Fig. 3). The rocks are intensely cleaved in the mélange zones. The long axes of the lenses of disrupted sandstone beds embedded in the matrix of schistose siltstone and mudstone are either subhorizontal or slightly inclined to the south, and have a west strike. There are numerous slickensides with subhorizontal or very gently plunging striations. A gradual transition is typical from the broken formation at the periphery of the mélange zone to the dismembered formation (Raymond, 1984) developed in its central part. As in the case of the first generation of thrust structures, it is highly difficult to estimate the amount of displacement along the strike-slip faults because of the absence of reliable stratigraphic markers. In course of 1:50000 geological survey in the region, the horizontal motion along the strike-slips was estimated at $1-2 \mathrm{~km}$. The presence of numerous small reverse left-lateral faults suggests the total amount of motion on northwest-striking strike-slip faults could have been several tens of kilometers. Farther east, in the Nal'chan fault zone, at the contact of the Nagondzha and Omulevka terranes (Fig. 1), two deformation stages have also been described, which are associated with the early thrusting and subsequent reverse left-lateral faulting (Prokopiev, 2000; Oxman and Prokopiev, 2000).

\section{Age of dislocations}

In both of the areas, the age of deformation is presumably Late Jurassic-Early Cretaceous. The Takalkan graniteporphyry pluton located $15 \mathrm{~km}$ to the north (Trunilina et al., 1999) with ${ }^{40} \mathrm{Ar} /{ }^{39} \mathrm{Ar}$ whole rock ages of $96.4 \pm 0.4$ and 97.0 $\pm 0.6 \mathrm{Ma}$ (Layer et al., 2001) and a quartz diorite stock with ${ }^{40} \mathrm{Ar} /{ }^{39} \mathrm{Ar}$ biotite ages of $134.3 \pm 0.4 \mathrm{Ma}$ intruded the folded strata and caused contact metamorphism. The Khulidzhyun area contains dikes of Early Cretaceous dioriteporphyry and Late Jurassic lamprophyres concordant to the tectonic mélange structures of the first generation and deformed, together with the tectonic mélange zone, by a second generation of strike-slip faults (Fig. 2). In the Setachan area, the tectonic mélange disrupts a lamprophyre dike of Late Jurassic age. This suggests a Late Jurassic-Early Cretaceous age of the first-stage deformation and a pre-Hauterivian age of the second-stage deformation in the study area.

\section{Conclusions}

Our analysis of the fold and fault structures we have described led us to propose the following paleotectonic scenario for the structural evolution of the region. In the Late Jurassic, a paleoocean, separating the Kolyma-Omolon microcontinent and the eastern margin of the North Asian craton closed and the first phase of frontal collision occurred. Synchronously the granitoids of Main batholith belt crystallized (Prokopiev et al., 2007). The deformations caused by

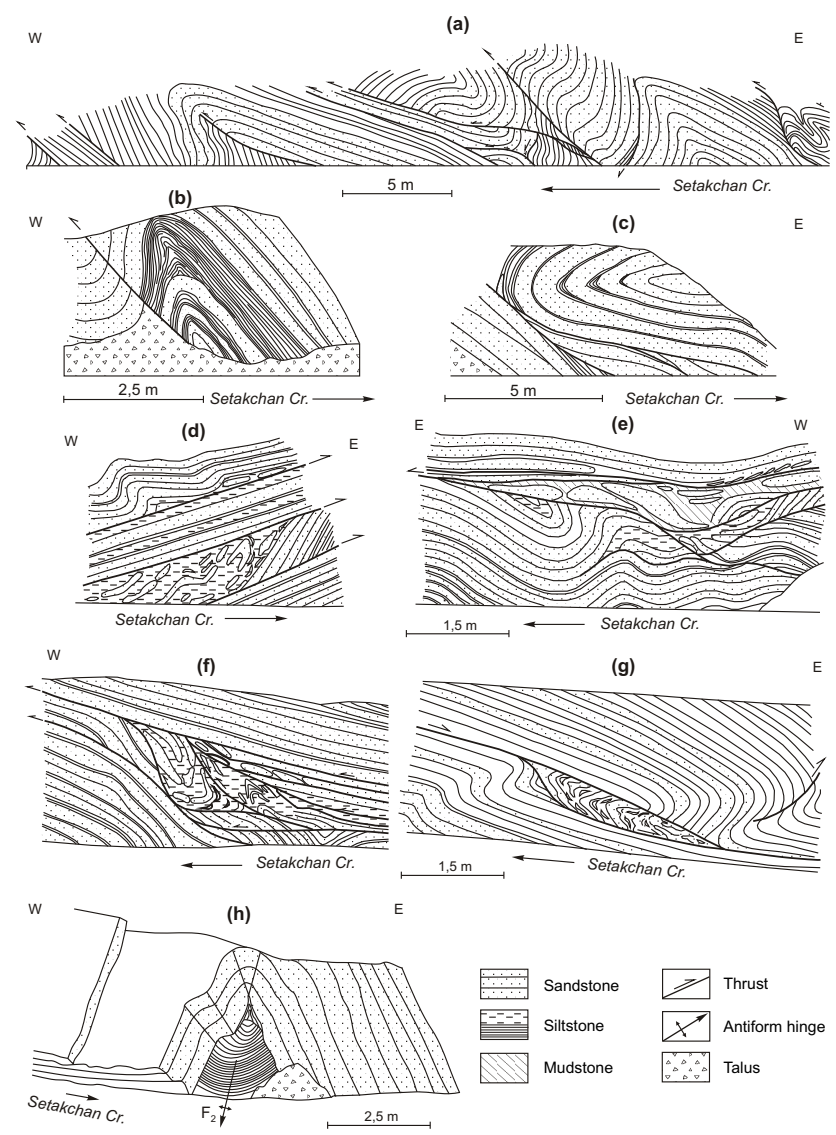

Fig. 4. Structures in the Upper Triassic strata, Setakchan area. (a, b) - thrusts and folds of the first generation. (c) - overturned antiform and thrust of the first generation. (d, e, f, g) - thrust microduplexes of the first generation. (h) - antiform of the second generation with a steeply plunging hinge line.

the first phase of the collision were not seen in the study areas located west of the frontal collision zone (Fig. 5a). In the Late Late Jurassic-Early Cretaceous, closure of a small gulf of the South Anyui ocean (Parfenov and Kuz'min, 2001) caused lateral motion of the microcontinent to the northwest, forming left-lateral strike-slips along the whole length of the Chersky Range. This second phase of collision resulted in folding and faulting in the study region, and crystallization of granitoids of the Northern batholith belt (Fig. 5b). Early in this phase, the collision of the northwestern margin of the microcontinent and the craton produced low-angle thrusts of the first generation (Fig. 6a). The thrusts of the Setakchan area may be regarded as deformation structures within the allocththon of the Setachan nappe, with its frontal part exposed within the Khulidzhyun area. At the end of the phase, the continued motion of the microcontinent led to the formation of reverse left-lateral faults and fault-plane contractional duplexes (Prokopiev and Kaskevich, 2000), and by the deformation of the earlier thrust structures (Fig. 6b). 


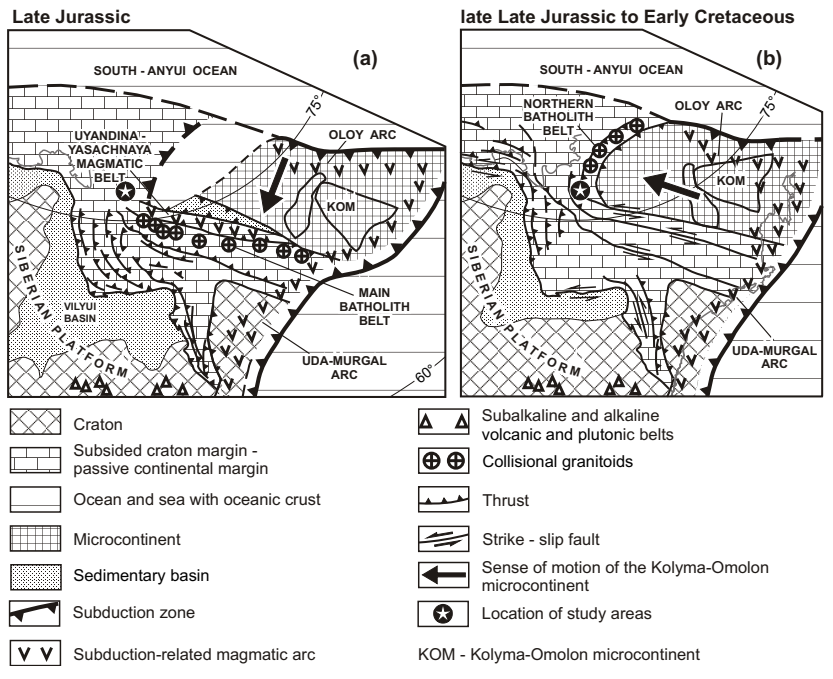

Fig. 5. Paleogeodynamic reconstructions of the zone of junction of the Kolyma-Omolon microcontinent and the eastern margin of the North Asian craton: (a) - for the Late Jurassic, (b) - for the Late Late Jurassic-Early Cretaceous. After Parfenov (1995), Parfenov and Kuz'min (2001), Parfenov et al. (2003) modified by the authors.

(a)
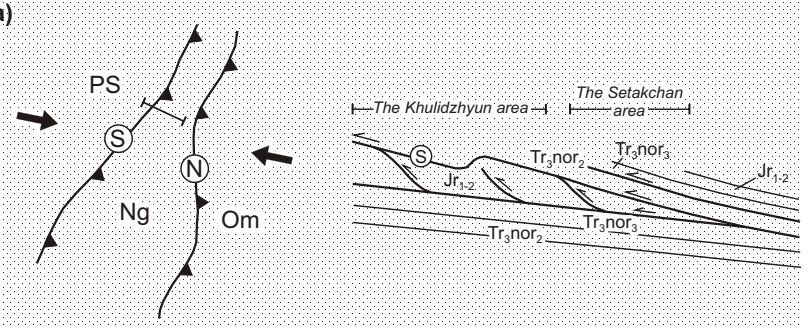

(b)

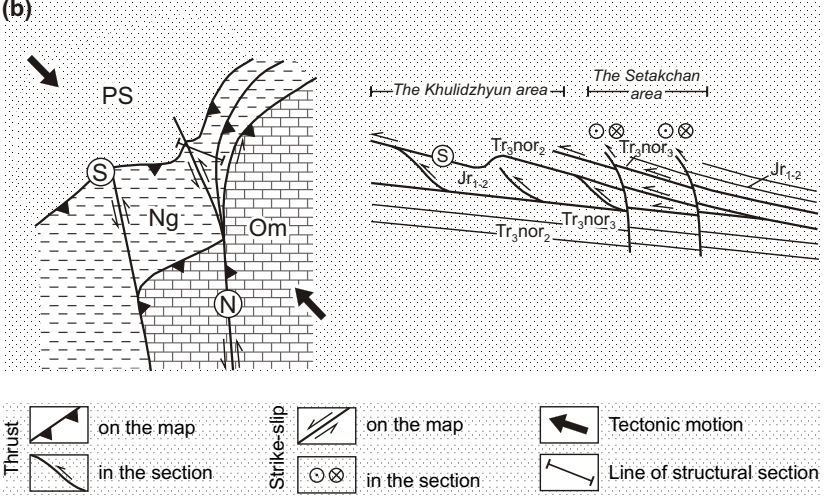

Fig. 6. Structural-kinematic evolutionary maps and structural sections of the zone of junction of the Polousnyy synclinorium, Nagondzha and Omulevka terranes. (a) - first stage, (b) - second stage of deformation. PS - Polousnyy synclinorium, Ng Nagondzha terrane, Om - Omulevka terrane. Faults: S - Setakchan, $\mathrm{N}-\mathrm{Nal}$ 'chan.
Acknowledgements. The authors thank David Stone and Catherine Hanks for critical comments, and Wesley K. Wallace for helpful review and for comments and corrections which were taken into consideration in the final manuscript preparation. Research was supported by projects RFBR (07-05-00743, 06-05-96070) and ONZ-7.10.2.

\section{References}

Grebennikov, G. A., Epov, O. G., Boyarshinov, V. V., et al.: Geologic map of Yakutia. Lower Yana block, Scale 1:500 000, Map's Printing-house of Russian Geological Research Institute, St.Petersburg, 1995 (in Russian).

Layer, P. W., Newberry, R., Fujita, K., Parfenov, L. M., Trunilina, V. A., and Bakharev, A. G.: Tectonic setting of the plutonic belts of Yakutia, Northeast Russia, based on ${ }^{40} \mathrm{Ar} /{ }^{39} \mathrm{Ar}$ and trace element geochemistry, Geology, 29, 167-170, 2001.

Oxman, V. S.: Tectonics of the Chersky collisional belt (northeast Asia), GEOS, Moscow, 269 pp., 2000 (in Russian).

Oxman, V. S. and Prokopiev, A. V.: Terrigenous tectonic mélanges of the Polousnyy synclinorium, Otechestvennaya Geologiya, 5, 47-50, 2000 (in Russian).

Parfenov, L. M.: Terranes and formation history of Mesozoic orogenic belts of east Yakutia, Tikhookean. Geol., 14(6), 32-43, 1995 (in Russian).

Parfenov, L. M., Berzin, N. A., Khanchuk, A. I., Badarch, G., Belichenko, V. G., Bulgatov, A. N., Dril, S. I., Kirillova, G. L., Kuzmin, M. I., Nokleberg, W. J., Prokopiev, A. V., Timofeev, V. F., Tomurtogoo, O., and Yang, H.: A model for the formation of orogenic belts in Central and Northeast Asia, Tikhookean. Geol., 22(6), 7-41, 2003 (in Russian).

Parfenov, L. M. and Kuz'min, M. I. (Eds.): Tectonics, geodynamics and metallogeny of the Sakha Republic (Yakutia), MAIK "Nauka/Interperiodica", Moscow, 571 pp., 2001 (in Russian).

Passchier, C. W. and Trouw, R. A. J.: Microtectonics, Springer, Berlin, 289 pp., 1996.

Prokopiev, A. V.: Verkhoyansk-Cherskiy collisional orogen, Geology of Pacific Ocean, 15, 891-904, 2000.

Prokopiev, A. V., Toro, J., Miller, E. L., Wooden, J., Trunilina, V. A., and Bakharev, A. G.: Granitoids of the Main batholith belt (northeast Asia): new U-Pb SHRIMP geochronological and geochemical data, Tectonics and metallogeny of the Circum North Pacific and East Asia, Khabarovsk, Institute of Tectonics and Geophysics, 286-288, 2007 (in Russian).

Prokopiev, A. V. and Kaskevich, G. E.: Strike-slip duplexes of eastern Yakutia (northeast Russia), Otechestvennaya Geologiya, 5, 44-46, 2000 (in Russian).

Raymond, L. A.: Classification of mélanges, in: Mélanges: their nature, origin, significance, Geological Society of America, Special Paper 198, 7-20, 1984.

Trunilina, V. A., Poev, S. P., Orlov, Yu. S., and Oxman, V. S.: Magmatism of different geodynamic environments (zone of junction of the Verkhoyansk margin of the Siberian continent and the Kolyma-Omolon microrontinent), Publishing House of Yakutian Scientific Centre, Siberian Branch, Russian Academy of Sciences, Yakutsk, 152 pp., 1999 (in Russian). 